examples. In that paper Dr. Stopes states the supposition that the Yarra calcarcous nodules are "more nearly approximate" to the clas-ironstone nodules of the Carboniferous. I was not aware, however, that these contained so large a proportion of woody material as we tind in the Yarra nodules, the regetable remains in the 'siderites' being usually in the form of impressions or carbonaceous films. The proportion of argillaceous matter, moreover, in the nodules from the Yarra, is exceedingly small, whilst the amonnt of calcareous material is comparatively large. Since I omitted to give the percentages in $\mathrm{my}$ paper on the subject, they are here appended. From the context of that paper it will be apparent that the qualifying term 'clay' (only once used in connection with these nodules) was a lapsus calami.

The analysis of the nodules from the Yarra estuary is as follows:Carbonaceous matter $=55$ per cent.; calcareous $=41$ per cent. ; arenaceous and argillaceous $=4$ per cent. With regard to the occurrence of quartz-grains, zircons, etc., in the Yarra nodules, it will be seen on consideration that these are accidental constituents of the matrix, due to local conditions, and which would in no respect affect the comparison; whilst the solidity and more completely calcified condition of the English 'coal-balls' could be accounted for by difference in age.

I have examined a large number of the English 'coal-balls,' both microscopically and in hand specimens, and had brought with me to Melbourne a number of characteristic examples, which I have used for comparative purposes. I am not in a position, however, to discuss their relation to the beds in which they occur, since I have not examined them in sitú ; and therefore await Dr. Stopes' detailed description with the greater interest. When these results are published we may perhaps also learn whether the stems of Calamites and twigs of Lepidodendron have been found actually passing from the nodules into the surrounding deposits. In conclusion, be the theory prored either way, personally speaking it will be equally satisfactory to know that the modus operandi of their formation has been successfully elucidated.

F. Chapman.

Natioxal Mussum, Melboure. April 16th, 1907 .

\title{
AN UNPCBLISHED LETTER OF SIR JOSEPH PRESTWICH ON SUBMERGENCE OF THE BRITISH ISLANDS IN PLEISTOCENE TIMES.
}

Sir,-At a time when the riews of those who, like mjself, hold that the partial submergence of the British Isles is the only way in which the existence of beds with marine shells of living species can be truly accounted for, hare been partially discredited by the address of the President of Section $\mathrm{C}$ at York last year, it may be well to produce the following letter of Sir Joseph Prestwich, upon which I hare accidentally lighted while turning over a book of geological memoranda written some years since. In explanation of this letter I may mention that it was written in answer to one from myself, in which I called 
the attention of the writer to the evidence of submersion as afforder? by the existence of the high-level shelly gravels of North Wales and Derbyshire, together with the existence of rolled quartz-pebbles scattered orer the Cottswold Hills of Gloncestershire, formed of Jurassic limestones, up to 600 fect abore sea-lerel; a fact corroborated by Professor J. Phillips in his "Geology of Oxford." With this preface I proceed to give Prestwich's letter:-

$$
\text { “25th July, } 1895 .
$$

"My dear Hull, -

Thanks for your letter. I quite agree with you as to the important submergence in Glacial times, which has left such clear evidence on the Cotteswold Hills and Welsh Mountains. It is surprising to me that the iceploughing hypothesis could ever be sustained. Some half-century ago it was $m y$ good fortune to come across one of the fossiliferous gravels in the hills (1100 feet) between Chesterfield and Buxton. Why the old simple explanation should ever have been pushed on one side in favour of the more fanciful view $I$ cannot understand, unless it be the innate love of chauge.

$$
\begin{aligned}
& \text { "I am, } \\
& \text { Very truly yours, } \\
& \text { Joseph PRESTwICH." }
\end{aligned}
$$

The shelly gravels of Moel Tryfaen, discovered by Trimmer many years since, are well known, having been often described; but those described by Nicholson as occurring at nearly the same level on the Denbighshire Hills (from 1070 to 1170 feet) have not been so generally recognised, and yet are important as indicating the lerel of submergence over a wide area. The beds occur on the ridge of Millstone Grit of Gloppa, near Oswestry. They are 60 feet in thickness, stratified, and contain numerous marine shells, of which some are living in the Irish Sea and are also found in the Moel Tryfaen beds (Q.J.G.S., vol. xlviii, p. 86).

Before concluding, it may be $\pi \mathrm{cll}$ in this connection to refer to the important paper by Mr. W. Shone on the "Glacial Deposits of West Cheshire" (Q.J.G.S., rol. xxxiv, p. 383), describing in detail the three divisions of the Drift Series as they are found in Lancashire and Cheshire, and the abundant marine fauna of the Upper Boulder-clay and Middle Sands as they occur near Newton Hollows in West Cheshire, both being underlain by the Lower Boulder-clay. The Upper Boulder-clay is stated to have yielded 57 species and rarieties of Mollusca, 2 Polyzoa, 26 Ostracoda, 3 Echini, and the Middle Sands contain 2 species of Cardium, also Tellina baltica and Turridella terebra; from the Lower Boulder Drift shells were absent, but erratic blocks numerous, offering a remarkable contrast to the overlaying marine beds. ${ }^{1}$ Those who, with Mr. Lamplugh, refuse to recognise an Interglacial (as well as Upper Glacial) marine stage of the Drift Series, are invited to read IIr. Shone's very instructive paper, which may be considered as descriptive of the Drift deposits as they occur generally throughout the north-west of England.

\section{4, Stanley Gardens, Nottixg Hill, W.}

Edward Hour. May $20 t h, 1907$.

1 See also Mr. R. D. Darbishire's paper on the shells from the Macclesfield Drift-beds: Grou. MAG., 1865, pp. 293-299, with a folding-table giving a list of 53 species found there. 